\title{
Public Sector Reform in Macao After the Handover
}

\author{
Bill K.P. Chou
}

\section{OpenEdition}

Journals

Édition électronique

URL : http://journals.openedition.org/chinaperspectives/808

DOI : 10.4000/chinaperspectives.808

ISSN : 1996-4617

\section{Éditeur}

Centre d'étude français sur la Chine contemporaine

\section{Édition imprimée}

Date de publication : 1 mars 2004

ISSN : 2070-3449

\section{Référence électronique}

Bill K.P. Chou, «Public Sector Reform in Macao After the Handover », China Perspectives [En ligne], 52 I march-april 2004, mis en ligne le 23 avril 2007, consulté le 28 octobre 2019. URL : http:// journals.openedition.org/chinaperspectives/808 ; DOI : 10.4000/chinaperspectives.808

Ce document a été généré automatiquement le 28 octobre 2019

(c) All rights reserved 


\title{
Public Sector Reform in Macao After the Handover
}

\author{
Bill K.P. Chou
}

1 In a situation where available resources are becoming scarce, governments in developed countries tend to face increasing public demand for improved government performance and accountability ${ }^{1}$. Most of the literature on public sector reform has been based on the experience of Western democracies ${ }^{2}$. Some have focused on examples from Asian and developing countries ${ }^{3}$. This paper seeks to present public sector reform in Macao following the handover from Portugal to China in December 1999.

Public sector and administrative problems in Macao

2 In 1999 Macao became China's second Special Administrative Region (SAR). Macao's public sector is small: in 2002, public consumption accounted for $11.41 \%$ of the territory's GDP4, with 17,488 civil servants in $2003^{5}$. The government did not hold major stakes in significant enterprises, with a few exceptions, such as TDM (Macao Television and Radio Broadcast) (100\% ownership) and Macao International Airport Company Ltd. (55.25\% ownership). It held an insignificant number of shares in a telecommunications company (1\%) and in the only electric company in the territory $(8.19 \%)^{6}$. The water supply company, Macao Water, was $100 \%$ privately owned. Owing to the limited government ownership of economic entities, the Macao government has limited room to economise its use of resources through privatisation and retreat from economic activities.

3 Macao's civil service was nevertheless expensive. The median monthly earnings of civil servants were the highest among the 13 top occupations, and more than three times the overall median in the territory ${ }^{7}$. Constitutional constraints tied the government's hands on pay cuts: Article 98 of the Macao Basic Law (Macao's mini-constitution) stipulated that civil servants were entitled to conditions of service no less than those before the handover ${ }^{8}$.

4 To economise on the use of resources, the government in recent years has often offered short-term and part-time contracts to public employees whose salary was much closer 
to market prices, and would usually renew the contracts upon contract expiry. Therefore, many of these types of employees were not temporary staff and served in the civil service for several years'. Since these employees were not regarded as civil servants and their number was not made public, the actual size of civil service was certainly larger than official figures stated.

5 The most high-ranking civil servants were the 58 bureau directors responsible to five Secretaries who directly reported to the Chief Executive, the head of the government. Bureau directors and their deputies belonged to director rank (lingdao). The administrative units below bureaus were organised into departments (ting), divisions $(c h u)$, sectors $(z u)$, and sections $(k e)$ in descending hierarchical order. The heads of these units were loosely classified as chief rank (zhuguan) ${ }^{10}$. The last two layers, sectors and sections, had no legal status in the Organic Statute of Macao Special Administrative Region $^{11}$.

6 The shortcomings of the civil service system had an adverse impact upon administrative efficiency. First, the government was by no means clear of traits of the spoil system inherited from the colonial government, and institutionalised a merit system in recruitment. Competitive recruitment examinations were not mandatory. Nepotism and patronage were rife and penetrated to lower-ranking positions. The five Secretaries were authorised to create positions; it was not unusual for them to create jobs for their supporters and relatives ${ }^{12}$. Open recruitment exercises were often symbolic $^{13}$. The promotion process was sometimes plagued by favouritism. For instance, a non legal-trained civil servant well-connected with her patron could be promoted to Deputy Director of Judicial Training Centre though the office bearer was supposed to have a background of legal training ${ }^{14}$.

7 The thaws in the performance appraisal system of Macao's civil service were another source of administrative problems. Civil servants had to undergo annual performance appraisal and were rated on a four-grade system: excellent, satisfactory, fair and poor. Civil servants rated excellent or satisfactory for two consecutive years were entitled to an upgrade within their pay scale. If contract staff were rated either fair or poor, their employment contracts were not renewed. In the case of permanent staff, those rated fair were unqualified for an increment; poor grades would result in disciplinary action. However, usually over $98 \%$ of civil servants were rated excellent or satisfactory: in $1999,5,746$ out of 9,269 civil servants (excluding those in the disciplinary forces) got an excellent grade and 3,496 were rated satisfactory. The remaining 27 were rated fair; none received poor grades. In the disciplinary forces, the distribution of employees over the four grades was $468(9 \%), 4,394(89 \%), 90(2 \%)$, and 0 (0\%) respectively. This implied that even mediocre civil servants could receive some sort of performancebased reward. Moreover, civil servants at director/chief level were not required to undergo performance appraisal. Thus civil servants were neither given adequate feedback on their past performance nor were there the incentives to improve their performance to move to a higher level ${ }^{15}$.

8 Moreover, civil servants had the right to reject job transfers that resulted in too many employees within a restructured department. In 1999 the government set up the Customs Service to take over enforcement of Intellectual Property Act from the Economic Services Bureau. As some civil servants refused to leave the Economic Services Bureau, the Bureau became overstaffed. In contrast, the Customs Service was understaffed and had to hire new employees ${ }^{16}$. 
The Legislative Assembly's lack of prowess and determination to closely scrutinise the administration was to blame for certain administrative problems. The Legislative Assembly had no equivalent of the specialised subcommittees that existed in the legislatures in other countries to examine government expenditure proposals on public works projects and the creation of senior posts. The government was not required to report to the Legislative Assembly on its expenditure once the annual budget was approved $^{17}$. Most members of the Legislative Assembly were pro-government, and unenthusiastic about supervising the government, holding it accountable for its policies, and institutionalising prudent public spending practices ${ }^{18}$.

10 For instance, in February 2004, the Legislative Assembly voted down a motion demanding the government to set up a public consultation mechanism in the lawmaking process ${ }^{19}$. In September 2002, the Commissioner of Audit (a commission performing cost-effective audits) exposed a scandal that involved the chairmen, vicechairmen, and full-time councillors of the former two Provisional Municipal Councils in abuse of public funds in 23 instances, such as using the councils' credit cards for shopping, overpaying housing allowances, and diverting housing allowances for the renovation of their own apartments ${ }^{20}$. Despite this situation, the Legislative Assembly voted down a motion requesting a public hearing and holding related officials responsible ${ }^{21}$. During the 2000-2001 session, 23 (out of the total 27) members submitted only 89 written questions and gave only 78 speeches on government work ${ }^{22}$.

11 Management of public finance was not insufficiently effective to detect and prevent wastage in time. About $15 \%$ of the government budget went to the government's 38 financial autonomous organisations. Unlike government departments, these autonomous organisations enjoyed high autonomy in spending. They were not obliged to submit their annual budgets and financial reports for the Legislative Assembly's approval. In the past, these autonomous organisations had known serious problems of abuse of public money, such as extravagances, under-the-table transactions, sale of public property to supporters at unreasonably low prices, illicit offers of loans, and intentional under-estimation of their own organisations' reserves to justify larger budget requests for the following year ${ }^{23}$.

12 To tighten controls on expenditure, the Macao government set up the Commission of Audit to scrutinise their spending and disclose financial mismanagement. Meanwhile, the government compressed the budgetary expenditure of the autonomous organisations from 6.52 billion in 2000 to 2.47 billion in 2004, and its own proportion of the government's gross budgetary expenditure from $35 \%$ to $15 \%{ }^{24}$. Nevertheless, inadequate manpower prevented the Commission of Audit from auditing the financial reports of all these autonomous organisations every year. In 2002, the Commission audited the financial reports of only ten autonomous organisations ${ }^{25}$. Hence, it was not until 2003 that the Commission discovered the Government Tourist Office's misuse of the Tourism Fund since $2000^{26}$.

13 Last but not least, many administrative units were overlapping in their roles. The Sports Development Bureau and the Civic and Municipal Affairs Bureau were both charged with managing sports facilities. The Lands, Public Work and Transport Bureau shared traffic management responsibilities with the Civic and Municipal Affairs Bureaus $^{27}$. The overlap was also to blame for bureaucracy in-fighting between the Civic and Municipal Affairs Bureau and the Cultural Institute, as both were responsible for organising performing arts activities, managing libraries and overseeing museums, and 
both wanted to expand their jurisdictions in art policy and administration ${ }^{28}$. Furthermore, such overlaps sometimes complicated administrative procedure and increased the items for administrative approval. An application for restaurant licences, for instance, required approval from the Civic and Municipal Affairs Bureau; Government Tourist Office; the police; fire services; Health Bureau; Cultural Institute; Labour Employment Bureau; and Land, Public Works and Transport Bureau ${ }^{29}$. Therefore restaurant owners had to wait for over half a year for a licence ${ }^{30}$.

The context and strategies of public sector reform

There are several factors that made undertaking sweeping public sector reform possible. The first was the popularity of the Chief Executive Edmund Ho. His approval rate ranged from $72 \%$ to $79 \%$ between March 2000 and February $2004^{31}$. Ho's popularity was partly due to his inheritance of his father Ho Yin's political assets. Before his death in 1983, Ho Yin had for over 30 years been the chief representative of the Chinese community, serving as a bridge between Peking and Lisbon, the colonial government and the public, and Chinese businessmen and the working class. He was a philanthropist and financed much of the enclave's social welfare at a time when the state-sponsored social services were far from adequate.

Edmund Ho was elected to the Legislative Assembly in 1988 and as vice-chairman of the Legislative Assembly in 1992. His position as the vice-chairman not only denoted his status as the chief representative of the Chinese community but also provided him with ample opportunities to develop his political skills before he took the helm of the SAR in $1999^{32}$. His success in stabilising the economy and public order, as discussed below, also contributed to his huge public following.

The second factor was the youth and inexperience of the civil servants. Possibly because of Portugal's hidden agenda of protecting Macanese interests and preserving the Portuguese cultural legacy after 1999, the colonial government in Macao dragged its feet in localisation policy ${ }^{33}$. In 1987, Macao had 1,076 Portugal-born civil servants, accounting for $10.69 \%$ of the total workforce. Their number peaked at 1,811 (12.35\% of all civil servants) in $1990^{34}$. Portuguese filled most of the senior positions. By the end of 1997 , only $14.81 \%$ and $40.00 \%$ of directors and deputy directors were local Chinese ${ }^{35}$. The Portuguese government alleged that the under-secretaries (the supervisors of bureau directors and the highest-ranking officials next to the Governor) were politically appointed but not career civil servants. Localisation did not extend to this rank, and therefore local people could not be promoted to this rank until after the handover ${ }^{36}$. Large scale replacement of Portuguese senior officials with Chinese civil servants took place only after 1998. In consequence, after the handover many of the senior civil servants were young and inexperienced. In 2001, only 99 out of 633 civil servants at director/chief rank were at the age of 45 or above $^{37}$. As a lot of high-ranking civil servants lacked senior administrative exposure, they were inclined to be submissive to authority. Political elites need not worry too much about a strong bureaucratic resistance of a type that had thwarted many countries' structural reforms ${ }^{38}$.

The third factor was the economic setback at the turn of the century. Gambling industry and tourism were the pillars of Macao's economy. Rampant organised crime kept tourists away and numbers fell from 8.15 million in 1996 to 6.95 million in $1998^{39}$. The impact this had on the gambling and tourist industry, together with the Asian financial crisis in 1997, pushed gambling tax revenue from its peak of MOP6.1 billion in 
1997 to below MOP5 billion in 1998 and $1999^{40}$. The real GDP growth rate fell from 3.3\% in 1995 to -4.6 in $1998^{41}$. The unemployment rate rose from $2.7 \%$ in the fourth quarter of 1997 to $7.1 \%$ in the second quarter of $2000^{42}$.

Public sector reform that could bring about cost savings, improvements in efficiency and service delivery was supposed to be a convenient vehicle for the enclave's posthandover government to bolster its legitimacy amid economic recession. However, in his 2000 policy plan, the Chief Executive identified four strategies characterised by an emphasis more on improving policy outcomes than saving on costs: restructuring departments, enhancing a customer-oriented culture, rationalising the use of resources and technology, and developing professional training for civil servants. There was no mention of how to reduce administrative stratification, regulate the authority of senior officials, and enhance the role of the Legislative Assembly or the Commission of Audit ${ }^{43}$. Strategies widely adopted by OECD countries, such as devolution of managerial authority, establishment of productivity targets and performance indicators, and exploration of alternatives to bureaucracy in service provision, were excluded ${ }^{44}$.

In the following three years, the government departments concerned specified Edmund Ho's reform programme strategies. To restructure departments, the government established the Civic and Municipal Affairs Bureau in 2001 to take over the functions of the Provisional Macao Municipal Council and Provisional Islands Macao Municipal Council ${ }^{45}$. Judicial police and security forces, traditionally opponents and belonging to separate functional bureaucracies, were placed under the uniform direction of the Unitary Police Service. The 2005 East Asian Games Office was incorporated. Macao Prison was removed from the Legal Affairs Bureau to become an independent bureaulevel department. The Post and Telecommunications Office was renamed the Post office, and its responsibility in telecommunications policy was transferred to a newly established office for the Development of Telecommunications and Information Technology. The Coloane-Taipa Reclamation office merged with the Incineration and Discharged Water Office to form the Office for Infrastructure Development ${ }^{46}$. The New Birth Registration Bureau merged with the Deceased Registration Bureau to form the Civil Affairs Registration Bureau ${ }^{47}$.

20 Many of these reform programmes however, missed the core issues. The department restructuring had little to do with resolving the problems of role overlapping, nor did it shrink the scope of government activities. Rather, the scope has expanded since the handover, as evidenced by the government's abolishing of two autonomous provisional municipal councils and turning them into a government department-the Civic and Municipal Affairs Bureau, as well as taking over TDM in 2002. Hence the impact of department restructuring on administrative efficiency was limited ${ }^{48}$.

The reform programmes regarding strengthening a customer-oriented environment included making performance pledges, setting up one-stop service centres, and establishing complaints offices in government departments. By the end of October 2003, 39 departments out of the total 45 departments providing direct public services had produced 840 performance pledges. Meanwhile, nine departments had set up 12 one-stop service centres aimed at simplifying administrative procedures by merging related departments into single offices ${ }^{49}$. Though one-stop service centres made making certain government-related applications easier, the items of administrative approval were reportedly not reduced. In fact, in order to overcome the hurdles caused by the items and ambiguities in administrative approvals, applicants were used to paying for 
services from middlemen who enjoyed reciprocity with the senior civil servants responsible for the approvals. Since removal of the approval items and ambiguities would dispense with the middlemen's service and undermine their interests, some departments had little incentive to simplify administrative procedures ${ }^{50}$.

With respect to using technology and resources more rationally, in 2001 the government formed a steering committee to study the development of electronic public administrative services, and installed an ISO9001 quality management system in departments and autonomous organisations. The first department using the system was the Identification Department ${ }^{51}$. In 2003, the government reviewed the civil service appraisal system to improve its feedback mechanisms on employee performance and oblige all civil servants at director/chief level to undergo annual appraisal. Appraisal commissions were set up in all departments to verify performance appraisal results and assure greater fairness and transparency. Nevertheless, this still did not address the issue of insufficient discrimination applied to the past performance appraisal system ${ }^{52}$.

In addition, the government proposed a staff transferral system ${ }^{53}$. Under the current system, opportunities of postings to other departments were very limited. Almost all promotion and staff redeployment took place within the same department. Even the most qualified civil servants were possibly barred from promotion if those more senior were younger and no new senior positions were available. This severely hindered career advancement opportunities and staff motivation ${ }^{54}$.

With regard to professional training, the government commissioned the Civil Service College of Singapore to provide an Executive Management Development Programme for over 600 middle- and high-ranking civil servants ${ }^{55}$. Job-related skills training covering law, secretarial work, management, computer skills, and language were stepped up ${ }^{56}$. Portuguese language training was a main component of language training as not many Chinese civil servants had a command of Portuguese. In 2001, less than $50 \%$ of civil servants could read and write both Chinese and Portuguese ${ }^{57}$. All official and legal documents produced before the handover were still in Portuguese. Owing to the meagre success of the localisation of the legal system and official use of Chinese language, only important policy announcements and decrees were translated into Chinese. Even though some decrees were in Chinese, they were sometimes incomprehensible because of tight translation schedules and the resulting poor quality of the translations ${ }^{58}$.

1. Size of public sector (1996-2000)

\begin{tabular}{|c|c|c|c|c|c|}
\hline Country/Region & Macaet ai & Hong Xong - Cir & singpore w & $\begin{array}{l}\text { Kow of } \\
\text { Zaalund }\end{array}$ & Xuw at to? \\
\hline $\begin{array}{l}\text { Population } \\
\text { (milios) }\end{array}$ & 0.437 & 6.77 & 4.0 & 383 & 198 \\
\hline Oarl pervents: & 19695 & 174550 & $124 \mathrm{pos}$ & $211 p O D$ & 250000 \\
\hline $\begin{array}{l}\text { Prqportionf chil seivantes } \\
\text { a) }\end{array}$ & 4.04 & 259 & 4. 33 & 551 & 1262 \\
\hline
\end{tabular}

NB : * Data 2002

(1) Including civilian employees and employees in education, health and police.

(2) Including civilian employees and employees in public schools and police.

(3) Including civilian employees

(4) Including civilian employees and employees in education and health sector.

Sources: Government of Macao Special Administrative Region Statistics, 2003. Macao: Human Resources Statistics, Public Administration and Civil Service Bureau, 2003. Statistics, Civil Service Bureau, the

Government of Hong Kong Special Administrative Regio, 2003. Hong Kong : The Facts - Population, 2003. Administrative and Civil Service Reform, World Bank Group, 2003, available at http:// www1.worldbank.org/publicsector/civilservice/development.htm. 
language issues may delay the administrative process. For instance, pollutants produced by an air-conditioned warehouse reportedly provoked many complaints. Although anti-pollution ordinances forbidding pollution were available, government officials were uncertain which provisions in the ordinance were breached ${ }^{59}$. Stepping up Portuguese language training was a necessary means to resolving a major administrative bottleneck. However, very often the time spent on training courses was not counted as work time, so there was little incentive to attend. In addition, the courses usually did not vigorously test the capacity of the trainees, and instructors were not well assessed. The quality of training courses could hardly be assured ${ }^{60}$.

Reasons for prudent public sector reform programmes relative strength of three major actors-bureaucrats, politicians, and society ${ }^{61}$. Given submissive bureaucrats and a civil society dependent on the government, politicians were the most influential actors in shaping policy outcomes ${ }^{62}$. Because of the high approval rate of the Chief Executive and the timidity of legislators as discussed, the reasons why many public sector reform programmes did not address the core issues of the administrative problems should be traced back to the Chief Executive.

The Chief Executive was more concerned about maintaining administrative stability than bashing the bureaucracy when it came to the quality of public service ${ }^{63}$. Also, in parallel with public opinion, the Chief Executive placed a higher priority on economic development and social order than public sector reform. In a survey conducted in March 2000, 44.5\% and 24.5\% of respondents regarded economic affairs and social order as the issues that concerned them most. Only $8.8 \%$ chose administrative problems ${ }^{64}$.

2000 , economic growth returned and in 2003 , the GDP at constant prices increased by $15.6 \%$. The unemployment rate dropped gradually to below $6 \%$ by the end of $2003^{65}$. Social order was also restored. In 2001, violent crime dropped by $25.3 \%$ compared with the previous year ${ }^{66}$. Visitor numbers increased and boosted gambling tax revenues to MOP 5.34 billion in 2000 and MOP 6.13 billion in 2001. In 2002, the government raised the gambling tax rate from $31.8 \%$ to $35 \%$. In 2003 a historical high of over MOP 9 billion in gambling tax revenue was recorded ${ }^{67}$. The government accumulated a big budget surplus (from MOP 314.2 million in 2000 to MOP 3.90 billion in 2003) ${ }^{68}$ and enjoyed high approval ratings (over 70\% between March 2000 and February 2004). A longitudinal study revealed that in 2001 Macao people were more satisfied with the government than in $1999^{69}$. Budget surplus and high approval ratings made it pointless to cut costs or bolster legitimacy through public sector reform which, as seen in many overseas examples, often stirs controversy within bureaucracy ${ }^{70}$.

The constraints of legal traditions may also account for a lack of sweeping reform measures. Macao inherited from Portugal a continental legal tradition. Unlike common law regions in which the exercise of executive power is sufficient to initiate farreaching structural reform ${ }^{71}$, regions with a tradition of codified civil law would be confronted with massive legal barriers and severely delayed in their pursuit of public sector reform ${ }^{72}$. For example, organic statutes regulated the set-up of government departments. Establishing new departments, abolishing old departments, modifying department functions, and changing department establishment all entail law amendments. Similarly, reforming staffing, performance appraisal systems, and staff transferral required amendments to the Civil Service Act. Given the necessity of bilingual (Chinese and Portuguese) legislation and a shortage of bilingual civil servants 
and legal experts, introduction of reform measures targeting the core issues of administrative problems cannot be realised in a short period of time.

Public sector reform in Macao did not address core problems in the public sector in Macao, i.e. poor personnel practices, the inadequate strength of the Legislative Assembly and the Commission of Audit, and the overlapping roles among government departments. This was due to a Chief Executive more concerned about economic issues and social order than public sector reform, in which some civil servants were inexperienced. Furthermore, drastic structural reform aimed at cutting costs was also deemed both unnecessary amid economic recovery, and impossible in a law-based administrative system.

\section{NOTES}

1. Vincent Wright, "The Paradoxes of Administrative Reform", in Walter J. M. Kickert (ed.), Public Management and Administrative Reform in Western Europe, Cheltenham, Edward Elgar, 1997, p. 17.

2. Hellmut Wollmann and Eckhard Schröter (eds.), Comparing Public Sector Reform in Britain and Germany: Key Traditions and Trends of Modernisation, Aldershot, Ashgate, 2000; Walter J. M. Kickert, "Anglo-Saxon Public Management and European Governance: The Case of Dutch Administrative Reforms," in Jan-Erik Lane (ed.), Public Sector Reform: Rationale, Trends and Problems, London, Sage, pp. 168-187.

3. Anthony B.L. Cheung and Ian Scott (eds.), Governance and Public Sector Reform in Asia: Paradigm Shifts or Business as Usual? London, Routledge Curzon, 2003; Ali Farazmand (ed.), Administrative Reform in Developing Nations, Westport, Praeger, 2002; Tom Kuotsai Liou (ed.), Administrative Reform and National Economic Development, Aldershot, Ashgate, 2000; Public Sector Board, World Bank, Reforming Public Institutions and Strengthening Governance: A World Bank Strategy, Washington DC, World Bank, Public Sector Group, Poverty Reduction and Economic Management (PREM) Network, 2000; Luiz Pereira, Bresser Carlos and Peter Spink, Reforming the State: Managerial Public Administration in Latin America, Boulder, Lynne Rienner Publishers, 1999; Ian Scott and Ian Thynne (eds.), Public Sector Reform: Critical Issues and Perspectives, Hong Kong, AJPA, 1994.

4. 2003 Macao in Figures, http://www.dsec.gov.mo/e_index.html. Accessed February 9th 2004.

5. Renli ziyuan tongji ziliao (Human Resource Statistics), http://www.safp.gov.mo/ external/chin/info/statistics/showdata.asp?table=1. Accessed February 7th 2004.

6. Aomen ribao (Macao Daily), October 9th 2002, p. A1; Macao International Airport, http:// www.macao-airport.com/partners_cam.phtml.

7. Employment Survey - $3^{\text {rd }}$ Quarter, 2002, Macao, Statistics and Census Service, Government of Macao Special Administrative Region, 2002, pp. 76-79.

8. The Basic Law of the Macao Special Administrative Region of the People's Republic of China, http://www.macao.gov.mo/constitution/basiclaw_en.phtml. Accessed March 10th 2003.

9. Interview with a retired personnel official on October 1 st 2003. 
10. 2001 Aomen tebie xingzheng qu gonggong xingzheng renli ziyuan baogao (A Report of Human Resources of Macao Special Administration Region Public Administration, 2001), Macao, Public Administration and Civil Service Bureau, 2002, pp. I-46.

11. Decree No.2/1999, http://www.imprensa.macau.gov.mo/bo/i/1999/01/lei02_cn.asp, Accessed February 10th 2004. See also Tao-chiu Lam, "Administration and Public Service System in Macau", in Rolf D. Cremer (ed.), Macau: City of Commerce and Culture, Hong Kong, API Press, 1991, p. 338.

12. Interview on November 8 th 2002. See also Aomen tebie xingzheng qu zhengfu lifahui huikan : di er jie di yi hui qi [2001-2002] di yi zhu di II-9 qi (Bulletin of Legislative Assembly of Macao SAR Government - No.II-9, First Committee [2001 - 2002]), December 3rd 2001, p. 9.

13. An insider told the author on December 12th 2003 that very often civil service examinations tested candidates' understanding on the internal administration of the departments which held the recruitment examinations. Therefore usually only the candidates from the departments knew the answers and passed the examinations. 14. Xinbao (Information Journal), February 15th 2003, p.3.

15. Minya Lao, "Guanyu Aomen tebie xingzheng qu zhengfu bumen gongzuo ping ke de baogao" (A Report of the Performance Appraisal System of Macao SAR Government), Xingzheng (Administration), Vol. 13, No. 4, 2000, pp. 1105-1127; “Aomen gonggong xingzheng gongzuo renyuan tongze" (Macao Civil Service Act), Aomen gongzhi falu zhidu (Ordinances of Macao Civil Service System), Macao, Public Administration and Civil Service Bureau and Government Printing Bureau, 1999, p. 179; Aomen ribao (Macao Daily), November 30th 2002, p. B1.

16. Aomen xingzheng qu zhengfu lifahui huikan: di er jie di yi hui qi [2001-2002] di yi zhu di II-9 $q i$.

17. Aomen tebie xingzheng qu zhengfu lifahui huikan: di yi jie di er hui qi [2000-2001] di er zhu di 13/2000 qi (Bulletin of the Legislative Assembly of Macao SAR Government - No. 13/2000, Second Committee [2000 - 2001]), November 24th 2000. Available at http:// www.al.gov.mo/diario/101/cs2-2/2000-13\%20\%20(11-24).pdf. Accessed March 4th 2003, pp. 20-21.

18. For details about the political background of Legislative Assembly members, see Bill K. P. Chou, "Interest Groups Politics in Macao", Journal of Contemporary China, forthcoming; Shiu-hing Lo, Political Development in Macao, Hong Kong, The Chinese University of Hong Kong, 1995.

19. Aomen ribao (Macao Daily), February 4th 2004, p. B3.

20. Aomen ribao (Macao Daily) (Internet Edition), September $7^{\text {th }} 2002$; September $8^{\text {th }}$ 2002.

21. Xin Aomen (New Macao), December 2002, pp. 5-6.

22. Macao Yearbook 2002, Macao, The Government Information Bureau of the Macao Special Administrative Region, 2002, p. 51.

23. Aomen tebie xingzheng qu shenjichu, Er ling ling ling niandu zhengfu zai chang yunzuo shenji baogao (Audit Report 2000), available at http://www.ca.gv.mo/ch/reports/ RAOF00cn.pdf. Accessed December 6th 2003.

24. Economic Services Bureau Public Finance, http://www.economia.gov.mo/chinese/ dei/chiind15.htm, accessed February 11th 2004.

25. Aomen tebie xingzheng qu shenjichu, Er ling ling yi niandu zhengfu zai chang yunzuo shenji baogao (Audit Report 2001). Available at http://www.ca.gov.mo/ch/reports/ RAOF01cn.pdf. Accessed March 6th 2003, p. 5. 
26. Aomen tebie xingzheng qu shenjichu, Zhuanxiang shenji baogao - luyou jijin zhangmu (Audit Report Special Issue - Tourism Fund) Available at http://www.ca.gov.mo/ch/ reports/SA203cn.pdf. Accessed February 4th 2004, p. 7.

27. Sports Development Bureau, http://venue.sport.gov.mo/sport/refer/facintro.jsp. Accessed March 30th 2003; Lands, Public Work and Transport Bureau, http:// www.dssopt.gov.mo/chin.htm. Accessed March 30th 2003.

28. Xinbao (Information Journal), August 24th 2003, p. 1.

29. A men ribao (Macao Daily), March 11th 2003, p. A10.

30. Aomen tebie xingzheng qu zhengfu lifahui huikan: di er jie di er hui qi [2002-2003] di yi zhu di II-31 qi (Bulletin of Legislative Assembly of Macao SAR Government - No.13/2000, Second Committee [2000-2001]), October 16th 2002. Available at http:// www.al.gov.mo/diario/102/cs1-2/2002-031\%20(10-16).pdf. Accessed March 4th 2003, p. 3.

31. Centre for Macau Studies of the University of Macau, Opinion Survey on "the First Policy Speech of the Chief Executive of Macao Special Administrative Region Delivered on $29^{\text {th }}$ March, 2000", Centre for Macau Studies of the University of Macau, Macao, 2000, p. 31; Centre for Macau Studies of the University of Macau, Opinion Survey on the "Third Policy Speech of the Chief Executive of Macao Special Administrative Region Delivered on $20^{\text {th }}$ November, 2001", Centre for Macau Studies of the University of Macau, Macao, 2001, p. 23; Centre for Macau Studies of the University of Macau , Opinion Survey on the "Fourth Policy Speech of the Chief Executive of Macao Special Administrative Region Delivered on $20^{\text {th }}$ November, 2002", Centre for Macau Studies of the University of Macau, Macao, 2002, p. 30; HKU Poll Site. Available at http://hkupop.hku.hk. Accessed February 10th 2004. 32. Yu Chun, "'Yi guo liang zhi' zai Xianggang he Aomen de shishi: lilun yu shijian" (Theories and Practices of Implementation of "One Country Two Systems" Principle in Hong Kong and Macau), International Conference on Public Management in $21^{\text {st }}$ Century: Opportunities and Challenges, January 10th -11th 2004, University of Macau, Macao, China.

33. Ming K. Chan, "Different Roads to Home: The Retrocession of Hong Kong and Macau to Chinese Sovereignty," Journal of Contemporary China, Vol. 20, No. 3, August 2003, p. 509.

34. 2001 Aomen tebie xingzheng qu gonggong xingzheng renliziyuan baogao (A Report of Human Resources of Macao Special Administration Region Public Administration, 2001), p. II-6.

35. Aomen gonggong xingzheng zaizhirenyuan zhi bendihua zhuang fang (Localization of Macao Civil Service), Macao, Public Administration and Civil Service Bureau, 1999, pp. 22-23.

36. Guomin Lu, “Gong wu yuan bendihua de kun jing yu dui ce”, (Problems and Solutions in Civil Service Localisation), in Yu Chun (ed.), Aomen huigui qianhou de wenti yu duice (Problems and Solutions around Macao's Handover), Hong Kong, Mingliu Press, 1999, pp. 94-100.

37. 2001 Aomen tebie xingzheng qu gonggong xingzheng renliziyuan baogao, p. I-46.

38. Grant Jordan and Barry J. O’Toole, “The Next Steps: Origins and Destinations”, in Barry J. O'Toole and Grant Jordan (eds.), Next Steps: Improving Management in Government, Aldershot, Dartmouth, 1995, p. 3; Andrew Gray and Bill Jenkins, "Implementing the Next Steps: A Choreography of Management Change", in Barry J. O'Toole and Grant Jordan (eds.), Next Steps: Improving Management in Government, p. 46; Yiuyu Kam, "Decision-Making and Implementation of Policy toward Hong Kong", in Hamrin Carol 
Lee and Zhao Suisheng (eds.), Decision-Making in Deng's China: Perspectives from Insiders, N.Y., M.E. Sharpe, 1995, p. 109.

39. Government of Macao Special Administrative Region Statistics. Available at http:// www.macao.gov.mo/index_en.html. Accessed March 7th 2003.

40. The exchange rate on May 1st 2003 was US\$1=MOP8 Aomen ribao (Macao Daily), January 29th 2003, p. A1.

41. Government of Macao Special Administrative Region Statistics.

42. Employment Survey (various years) Macao, Statistics and Census Service, Government of Macao Special Administrative Region.

43. Government Policy Plan for the Year 2000 Financial Year of the Macao Special

Administrative Region of the People's Republic of China, the Chief Executive Edmund Ho, March 29th 2000. Available at http://www.macao.gov.mo/policy/en2000_policy.pdf. Accessed March 8th 2003, pp. 11-12.

44. OECD, Governance in Transition: Public Management Reforms in OECD Countries, Paris, OECD, 1995, p. 8.

45. Civic and Municipal Affairs Bureau. http://www.iacm.gov.mo/iacm2002_c.htm. Accessed March 6th 2003.

46. 2001 Aomen tebie xingzheng qu gonggong xingzheng renliziyuan baogao, p. I-10.

47. Xingzheng fawu fanwei, Aomen tebie xingzheng qu zhengfu er ling ling san nian caizheng niandu shizheng baogao (The Administration and Justice Policy Areas Plan, Policy Address for the Fiscal Year 2003 of the Government of the Macao Special Administrative Region of the People's Republic of China). Available at http:// www.macao.gov.mo/live2003/chinese/cn2003_aj.pdf. Accessed March 30th 2003, p. 5. 48. Xingzheng fawu fanwei, Aomen tebie xingzheng qu zhengfu er ling ling si nian caizheng niandu shizheng baogao (The Administration and Justice Policy Areas Plan, Policy Address for the Fiscal Year 2004 of the Government of the Macao Special Administrative Region of the People's Republic of China). Available at http:// www.macao.gov.mo/policy2004/chinese/aj04_cn.doc. Accessed February 8th 200, p. 4. 49. Xingzheng fawu fanwei, Aomen tebie xingzheng qu zhengfu er ling ling si nian caizheng niandu shizheng baogao, p. 4.

50. Interview with a senior civil servant on November 24th 2003.

51. Xingzheng fawu fanwei, Aomen tebie xingzheng qu zhengfu er ling ling si nian caizheng niandu shizheng baogao, p. 6.

52. Aomen ribao (Macao Daily), November 15th 2003, p. A6.

53. Aomen ribao (Macao Daily), December 21st 2003, p. A3.

54. Consultation meeting with civil servants' representatives on June 17th 2003.

55. Xingzheng fawu fanwei, Aomen tebie xingzheng qu zhengfu er ling ling yi nian caizheng niandu shizheng baogao (The Administration and Justice Policy Areas Plan, Policy Address for the Fiscal Year 2001 of the Government of the Macao Special Administrative Region of the People's Republic of China). Available at http:// www.macao.gov.mo/policy/cn2001_policy.pdf. Accessed March 30th 2003; Xingzheng fawu fanwei, Aomen tebie xingzheng qu zhengfu er ling ling er nian caizheng niandu shizheng baogao (The Administration and Justice Policy Areas Plan, Policy Address for the Fiscal Year 2002 of the Government of the Macao Special Administrative Region of the People's Republic of China). Available at http://www.macao.gov.mo/policy/ cn2002_policy.pdf. Accessed March 30th 2003.

56. Macao Yearbook 2002, p. 86. 
57. Aomen tebie xingzheng qu zhengfu lifahui huikan: di er jie di yi hui qi [2001-2002] di yi zhu di II-9 qi, pp. 14-18.

58. Interview on February $3^{\text {rd }} 2004$ with a former senior official responsible for law translation.

59. New Macao Society. Available at http://home.macao.ctm.net/ newmacao/ Accessed March $30^{\text {th }} 2003$.

60. The claims were based on the author's experience as an instructor of two management courses for middle- and high-ranking civil servants, as well as some of the course attendees' opinions.

61. Myung-Jae Moon and Patricia Ingraham, "Shaping Administrative Reform and Governance: An Examination of the Political Nexus Triads in Three Asian Countries", Governance: An International Journal of Policy and Administration, Vol. 11, No. 1, pp. 77-100. 62. ' Bill K. P. Chou, "Public Sector Reform in Macau and Hong Kong: An Examination of the Political Nexus Triads in the Two China's Special Administrative Regions", International Conference on Public Management in $21^{\text {st }}$ Century: Opportunities and Challenges, January 10th -11th 2004, University of Macau, Macao, China.

63. Government Policy Plan for the Year 2000, March 29t 2000, p.6.

64. Centre for Macau Studies of the University of Macau, Opinion Survey on the "First Policy Speech of the Chief Executive of Macao Special Administrative Region Delivered on 29th March, 2000", p.7.

65. Employment Survey, various years.

66. Macao Yearbook 2002, p. 89.

67. Economic Services Bureau, Public Finance.

68. Economic Services Bureau, Public Finance.

69. Robert T.Y. Chung, “Aomen huigui liang zhou nian minqing fazhan" (The Public Opinion of Macao upon the Second Anniversary of Transfer of Sovereignty), in Aomen 2002 (Macao 2002), Macao, Macao Foundation, 2002, p. 43.

70. Charles H. Levine, “Organizational Decline and Cutback Management”, in Richard C. Kearney and Evan M. Berman (eds.), Public Sector Performance: Management, Motivation, Measurement, Boulder, Westview Press, 1999, p. 233.

71. Kickert, “Anglo-Saxon Public Management and European Governance: The Case of Dutch Administrative Reforms", op. cit., p. 42.

72. Christoph Reichard, “'Neues Steuerungsmodell': Local Reform in Germany”, in Kickert (ed.), Public Management and Administrative Reform in Western Europe, op. cit., p. 60.

\section{INDEX}

Thèmes : politique 